\title{
Deniquelata vittalii sp. nov., a novel Indian saprobic marine fungus on Suaeda monoica and two new records of marine fungi from Muthupet mangroves, East coast of India
}

\author{
Devadatha $B^{1}$, Sarma VV ${ }^{1 *}$, Ariyawansa $\mathrm{HA}^{2}$ and Gareth Jones EB ${ }^{3,4}$ \\ ${ }^{1}$ Fungal Biotechnology Lab, Department of Biotechnology, School of Life Sciences, Pondicherry University, Kalapet, \\ Pondicherry-605014, India \\ ${ }^{2}$ Department of Plant Pathology and Microbiology, National Taiwan University, Taipei, Taiwan \\ ${ }^{3}$ Division of Plant Pathology, Department of Entomology and Plant Pathology, Faculty of Agriculture, Chiang Mai \\ University, Chiang Mai 50200, Thailand \\ ${ }^{4}$ Nantgaredig, 33B St. Edwards Road, Southsea, Hants., PO5 3DH, UK
}

Devadatha B, Sarma VV, Ariyawansa HA, Gareth Jones EB 2018 - Deniquelata vittalii sp.nov., a novel Indian saprobic marine fungus on Suaeda monoica and two new records of marine fungi from Muthupet mangroves, East coast of India. Mycosphere 9(3), 565-582, Doi 10.5943/mycosphere/9/3/8

\begin{abstract}
Deniquelata vittalii, a novel species of marine fungi in the genus Deniquelata, found saprobic on a decaying woody stem of the halophyte Suaeda monoica, collected from Muthupet mangroves, southeast coast of India is described and illustrated in this paper. Morphologically D. vittalii resembles $D$. barringtoniae, but it is distinct in having larger ascomata, asci and golden yellow to dark brown ascospores with 3-6 transverse septa. Phylogenetic analyses inferred from combined LSU, SSU and ITS datasets indicate that $D$. vittalii shares a sister relationship with $D$. barringtoniae with high statistical support and forms a strongly supported monophyletic clade. Both morphological differences and DNA based sequence data strongly support the establishment of the new taxon. New records of Farasanispora avicenniae and Hysterium rhizophorae are also reported in this paper supplemented with molecular sequence data.
\end{abstract}

Key words - Dothideomycetes - Didymosphaeriaceae - Pleosporales - Mangrove Fungi Molecular phylogeny

\section{Introduction}

Didymosphaeriaceae was introduced by Munk (1953), which is typified by Didymosphaeria Fuckel with $D$. epidermidis as the type species. This family is characterized by brown, thickwalled, 1-septate ascospores and trabeculate pseudoparaphyses, which anastomose above the asci in a gelatinous matrix and includes 25 accepted genera (Aptroot 1995, Hyde et al. 2013, Ariyawansa et al. 2014a, b, Wijayawardene et al. 2017). However, very few genera were reported in this family from marine based habitats (Jones et al. 2015).

The monotypic genus Deniquelata Ariyawansa \& K.D. Hyde was established by Ariyawansa et al. (2013) to accommodate Deniquelata barringtoniae Ariyawansa \& K.D. Hyde, found as a pathogen on living leaves of Barringtonia asiatica (Lecythidaceae). Both morphology and phylogenetic analyses of a concatenated dataset of the SSU and LSU rDNA supported Deniquelata 
as a new genus within Montagnulaceae, which was later synonymized and transferred to Didymosphaeriaceae based on its sister group relationship to Bimuria D. Hawksw., Chea \& Sheridan and Tremateia Kohlm., Volkm-Kohlm. \& OE. Erikss. (Ariyawansa et al. 2013, 2014b). This genus is characterized by ascomata that are immersed, globose to sub-globose, dark brown to black, asci bitunicate, clavate to broadly-clavate with a short furcate pedicel. Ascospores oblong to narrowly oblong, reddish brown to dark yellowish brown, muriform with three transverse septa and 1-2 vertical septa, verruculose and lacking a sheath (Ariyawansa et al. 2013).

Farasanispora Abdel-Wahab, Bahkali \& E.B.G. Jones is a monotypic genus established by Li et al. (2016) to accommodate Farasanispora avicenniae Abdel-Wahab, Bahkali \& E.B.G. Jones recorded on decaying wood of Avicennia marina from Farasan Island. Phylogenetic analysis of a concatenated dataset of the SSU and LSU rDNA supported Farasanispora as a new genus within Pleosporales and related to well established families such as Trematosphaeriaceae, Ascocylindricaceae and Morosphaeriaceae that are known to harbour marine fungi. However, any close affinities to other genera or an accurate position within a particular family remained unresolved ( $\mathrm{Li}$ et al. 2016). Currently the genus is monotypic with Farasanispora avicenniae.

The genus Hysterium was circumscribed by morphological characteristics such as hysterothecial, pigmented, carbonaceous ascomata and ascospores that are 3 or more transverselyseptate (Bisby 1923). The recent molecular studies showed that the species of Hysterium are polyphyletic (Schoch et al. 2009). Hyde et al. (2017) reported Hysterium rhizophorae, a new species, from Rhizophora apiculata based on the differences in the asci and ascospore dimensions in contrast with $H$. angustatum, which also formed a distinct lineage in the phylogenetic analyses.

We have reported some new species from our ongoing studies on biodiversity of marine fungi from Muthupet mangroves, Tamil Nadu, south east coast of India (Devadatha et al. 2017, 2018, Devadatha \& Sarma 2018). In the present study, we introduce a new species Deniquelata vittalii in Deniquelata based on morphological characters and phylogenetic analyses. Further, two new records of marine fungi to India, viz., Farasanispora avicenniae and Hysterium rhizophorae are also reported in this paper supplemented with molecular sequence data.

\section{Materials \& Methods}

\section{Sample collection and morphological studies}

Decaying mangrove woody stem pieces of the halophyte Suaeda monoica Forssk. ex J.F. Gmel and Aegiceras corniculatum (L.) Blanco were collected from Muthupet mangroves $\left(10.4{ }^{\circ} \mathrm{N}\right.$, $\left.79.5^{\circ} \mathrm{E}\right)$, Kaveri River Delta, Tamil Nadu, southeast coast of India as detailed in Devadatha et al. (2017). Specimens were incubated in moist chambers and examined under an Optika stereo zoom SZM-LED1 microscope. Hand sections of the ascomata were taken, where necessary, and the spore mass contents were scooped out with the help of forceps or a needle and mounted in sterile sea water and/or Lactophenol to observe the microscopic characters. Images were captured using Nikon ECLIPSE TiU upright microscope with DIC objectives connected to Nikon DS-Fi2 digital camera.

Single spore isolation was performed as described in Chomnunti et al (2014) with the modifications outlined in Devadatha et al. (2017). The herbarium specimens and the type cultures were deposited in the Ajrekar Mycological Herbarium (AMH) and National Fungal culture collection of India (NFCCI), Agharkar Research Institute (ARI), Pune, India. Facesofffungi and MycoBank numbers are provided (Jayasiri et al. 2015, MycoBank 2017).

\section{DNA extraction, PCR amplification and sequencing}

Genomic DNA was extracted from the axenic cultures grown on Malt Extract Agar (MEA) medium by using the DNeasy plant DNA extraction kit (QIAGEN, Germany) following the manufacturer's protocol. In this study, several loci were amplified using known universal primer pairs: ITS1 and ITS4 to amplify ITS region and nuclear small subunit rDNA region (SSU) was amplified using NS1 and NS4 (White et al. 1990). Nuclear large subunit rDNA (LSU) was amplified using LR0R and LR5 (Vilgalys \& Hester 1990). The translation elongation factor 1-alpha 
gene (TEF-1 $\alpha$ ) was amplified using primers EF1-983F and EF1-2218R (Rehner \& Buckley 2005). The RNA polymerase II second largest subunit (RPB2) gene was amplified using the fRPB2-5F and fRPB2-7cR primer (Liu et al. 1999).

The amplifications were performed employing $50 \mu \mathrm{L}$ of Polymerase chain reaction (PCR) mixtures containing $5 \mu \mathrm{L}$ of $10 \mathrm{X}$ Ex Taq buffer, $4 \mu \mathrm{L}$ of deoxy nucleotide triphosphate mixture (2.5 mM of each dNTP), $1 \mu \mathrm{L}$ of each primer $(10 \mu \mathrm{M}), 2 \mu \mathrm{L}$ of DNA template, $0.25 \mu \mathrm{L}$ of Takara EX Taq polymerase and $36.75 \mu \mathrm{L}$ of Nuclease free water. The PCR amplification conditions and amplified PCR amplicons were purified as reported in Devadatha et al. (2018). The purified PCR products were sequenced at Macrogen Inc. (Seoul, Korea).

\section{Phylogenetic analyses}

Taxa used in the phylogenetic analyses were obtained based on the BLAST search similarity resulted from LSU and ITS regions and through published literature (Ariyawansa et al. 2013, 2014a, b) for the taxonomic placement of Deniquelata vittalii. Multi-gene phylogenetic analyses of combined LSU, SSU, ITS, TEF-1 $\alpha$, RPB2 sequence data were performed for Farasanispora avicenniae (Li et al. 2016) and Hysterium rhizophorae (Hyde et al. 2017), based on the published data. Multiple sequence alignments for individual regions were generated online at MAFFT server (http://mafft.cbrc.jp/alignment/server/) (Katoh \& Standley 2013) and alignments were improved manually using BioEdit, where necessary. The individual sequence datasets (LSU, SSU, ITS, TEF1 $\alpha$, RPB2) were combined using BioEdit v.7.0.5.2 (Hall 1999). Three different datasets were prepared for the multigene phylogenetic analyses.

Maximum-parsimony analysis was performed by using PAUP v.4.0b10 (Swofford 2002) software to generate the most parsimonious trees. Trees were inferred using the heuristic search option with 1000 random sequence additions, with maxtrees set at 1000. Descriptive tree statistics for parsimony; Tree Length (TL), Consistency Index (CI), Retention Index (RI), Relative Consistency Index (RC) and Homoplasy Index (HI) were calculated for trees generated under different optimality criteria. The Kishino-Hasegawa tests (Kishino \& Hasegawa 1989) were performed in order to determine whether trees were significantly different. Maximum parsimony bootstrap values (MP) equal or greater than $70 \%$ are given above each node for Figure 1 and equal or greater than $75 \%$ for Figs 2, 3 .

The evolutionary models for phylogenetic analyses were selected for each gene using MrModeltest v. 2.3 (Nylander 2004) under the Akaike Information Criterion (AIC) as implemented in both PAUP v. $4.0 \mathrm{~b} 10$ and Mr. Bayes v.3.1.2. GTR+I+G model was selected as the most appropriate in each locus for Bayesian analysis and maximum-likelihood by AIC in MrModeltest as the best-fit model.

Bayesian analysis was performed with MrBayes v. 3.1 .2 (Huelsenbeck \& Ronquist 2001) to evaluate Bayesian posterior probabilities (BYPP) (Rannala \&Yang 1996, Zhaxybayeva \& Gogarten 2002) by Markov Chain Monte Carlo sampling (BMCMC). GTR $+\mathrm{I}+\mathrm{G}$ was used in the command. Six simultaneous Markov chains were run for 1,000,000 generations and trees were sampled every 100th generation (resulting in 10001trees). The distribution of log-likelihood scores was examined to determine stationary phase for each search and to decide if extra runs were required to achieve convergence, using the program Tracer 1.4 (Rambaut \& Drummond 2007). First 20\% of generated trees were discarded and remaining $80 \%$ trees were used to calculate posterior probabilities in the majority rule consensus tree. BYPP greater than 0.95 are given above each node (Figs. 1, 2, 3).

RAxML-HPC2 on XSEDE (8.2.8) (Stamatakis et al. 2008, Stamatakis 2014) in the CIPRES Science Gateway platform (Miller et al. 2010) was used to construct a maximum likelihood (ML) tree. Maximum Likelihood bootstrap values greater than $70 \%$ were given above each node for (Fig. 1) and equal or greater than $75 \%$ for (Figs. 2, 3).

The Phylogenetic trees were viewed in FigTree v1.4.0 program (Rambaut 2012) and reorganized in Microsoft power point (2016) and Adobe Illustrator ${ }^{\circledR}$ CS5 (Version 15.0.0, Adobe®, San Jose, CA). Novel sequences generated in the current study were deposited in GenBank (Tables 
$1,2,3)$ and the finalized alignment and tree of Deniquelata vittalii were deposited in TreeBASE, submission ID: 22390 (http://www.treebase.org/).

\section{Results}

\section{Phylogenetic analyses}

The first phylogenetic analyses were carried out with 24 sequences with our new taxon and strains from Didymosphaeriaceae, with Stemphylium vesicarium and Stemphylium botryosum as the outgroup taxa using combined LSU, SSU and ITS gene datasets (Table 1). Three different alignments corresponding to each individual gene and a combined alignment of the three genes were analyzed. The maximum parsimony dataset consists of 2332 characters with 1848 characters as constant, 311 characters were counted as parsimony-informative and 173 characters as parsimony-uninformative. The parsimony analyses resulted in two equal parsimonious trees with a tree length of 974 steps, $\mathrm{CI}=0.633, \mathrm{RI}=0.661, \mathrm{RC}=0.419, \mathrm{HI}=0.367$ values. $\mathrm{RAxML}$ analysis yielded a best scoring tree (Fig. 1) with a final ML optimization likelihood value of -8221.245191. The matrix had 586 distinct alignment patterns, with $16.69 \%$ of undetermined characters or gaps. Estimated base frequencies were as follows; $\mathrm{A}=0.247437, \mathrm{C}=0.227513, \mathrm{G}=0.277892, \mathrm{~T}=$ 0.247158; substitution rates $\mathrm{AC}=1.689545, \mathrm{AG}=2.522196, \mathrm{AT}=1.252478, \mathrm{CG}=0.689774, \mathrm{CT}=$ $6.758270, \mathrm{GT}=1.000$; proportion of invariable sites $\mathrm{I}=0.576761$; gamma distribution shape parameter $\alpha=0.582903$. The Bayesian analyses resulted in 10001 trees after 1,000,000 generations. The first 2000 trees, representing the burn-in phase of the analyses, were discarded, while the remaining 8001 trees were used for calculating posterior probabilities in the majority consensus tree for all the phylogenetic analyses (Figs 1, 2, 3). Phylogenetic trees obtained from ML, MP and Bayesian analyses yielded trees with similar topology and congruent with previous work-based on MP, ML and Bayesian analyses (Ariyawansa et al. 2013, 2014b). MP tree is shown with the bootstrap support (BS) values of MP and ML ( $\geq 70 \%)$ and Bayesian posterior probabilities (BYPP) greater than 0.95 are shown above the internal branches respectively (Fig. 1).

Table 1 GenBank and culture collection accession numbers of species included in the phylogenetic study of Deniquelata vittalii. Sequences generated in this study are in blue.

\begin{tabular}{|c|c|c|c|c|}
\hline \multirow{2}{*}{ Taxon } & \multirow{2}{*}{ Voucher/ Culture } & \multicolumn{3}{|c|}{ GenBank Accessions } \\
\hline & & ITS & LSU & SSU \\
\hline Alloconiothyrium aptrootii & CBS 980.95 & JX496121 & JX496234 & - \\
\hline Bimuria novae-zelandiae & CBS 107.79 & - & AY016356 & AY016338 \\
\hline Deniquelata barringtoniae & MFLUCC 11-0257 & KM213997 & KM214000 & KM214003 \\
\hline Deniquelata barringtoniae & MFLUCC 11-0422 & JX254654 & JX254655 & JX254656 \\
\hline Deniquealta vittalii & NFCCI4249 & MF406218 & MF182395 & MF622059 \\
\hline Didymocrea sadasivanii & CBS 438.65 & - & DQ384103 & DQ384066 \\
\hline Didymosphaeria rubi-ulmifolii & MFLUCC 14-0023 & - & KJ436586 & KJ436588 \\
\hline Kalmusia spartii & MFLUCC 14-0560 & KP744441 & KP744487 & KP753953 \\
\hline Karstenula rhodostoma & CBS 691.94 & - & AB807531 & AB797241 \\
\hline Laburnicola muriformis & MFLUCC 16-0290 & KU743197 & KU743198 & KU743199 \\
\hline Letendraea cordylinicola & MFLUCC 11-0150 & KM213996 & KM213999 & KM214002 \\
\hline Leptosphaerulina australis & CBS 317.83 & GU237829 & FJ795500 & GU296160 \\
\hline Montagnula cirsii & MFLUCC 13-0680 & KX274242 & KX274249 & KX274255 \\
\hline Neokalmusia brevispora & KT 2313 & LC014574 & AB524601 & AB524460 \\
\hline Paraphaeosphaeria michotii & MFLUCC 13-0349 & KJ939279 & KJ939282 & KJ939285 \\
\hline Paraconiothyrium hawaiiense & CBS 120025 & JX496027 & JX496140 & EU295655 \\
\hline Phaeodothis winteri & CBS 182.58 & - & DQ678073 & DQ678021 \\
\hline Pseudopithomyces chartarum & UTHSC 04-678 & HG518060 & HG518065 & - \\
\hline Stemphylium vesicarium & CBS 191.86 & KC584239 & GU238160 & GU238232 \\
\hline Stemphylium botryosum & CBS 714.68 & KC584238 & KC584345 & KC584603 \\
\hline Pseudocamarosporium corni & MFLUCC 13-0541 & KJ747048 & KJ813279 & - \\
\hline Spegazzinia tessarthra & Yone 211 & JQ673429 & AB807582 & AB797294 \\
\hline Tremateia arundicola & MFLUCC $16-1275$ & KX274241 & KX274248 & KX274254 \\
\hline Xenocamarosporium acaciae & CPC 247.55 & KR476724 & KR476759 & - \\
\hline
\end{tabular}


Table 2 GenBank and culture collection accession numbers of species included in the phylogenetic study of Farasanispora avicenniae. Sequences generated in this study are in blue.

\begin{tabular}{|c|c|c|c|c|c|c|}
\hline \multirow{2}{*}{ Taxon } & \multirow{2}{*}{$\begin{array}{l}\text { Voucher/ } \\
\text { Culture }\end{array}$} & \multicolumn{5}{|c|}{ GenBank Accessions } \\
\hline & & LSU & SSU & ITS & TEF1a & RPB2 \\
\hline Aegeanispora elanii & MAW-2017 & KY026052 & KY026051 & - & - & - \\
\hline Aquilomyces patris & CBS135661 & KP184041 & KP184077 & NR137961 & - & - \\
\hline Ascocylindrica marina & MD6011 & - & KT252907 & & - & - \\
\hline Ascocylindrica marina & MD6012 & KT252906 & - & & - & - \\
\hline Camarographium koreanum & CBS 117159 & JQ044451 & - & JQ044432 & - & - \\
\hline Clypeoloculus akatensis & KT788 & AB807543 & AB797253 & AB809631 & AB808519 & - \\
\hline Halomassarina thalassiae & BCC 17054 & GQ925849 & GQ925842 & - & - & - \\
\hline Halomassarina thalassiae & BCC 17055 & GQ925850 & GQ925843 & - & - & - \\
\hline Helicascus elaterascus & KT2673 & AB 807533 & AB797243 & AB809626 & AB808508 & - \\
\hline Helicascus nypae & ВCC 36751 & GU479788 & GU479754 & & GU479854 & GU479826 \\
\hline Falciformispora lignalitilis & BCC21118 & GU371827 & GU371835 & KF432943 & GU371820 & \\
\hline Falciformispora senegalensis & CBS19679 & KF015631 & KF015636 & KF015673 & KF015687 & KF015717 \\
\hline Falciformispora tompkinsii & CBS20079 & KF015625 & KF015639 & NR132041 & KF015685 & KF015719 \\
\hline Farasanispora avicenniae & MF1207 & KT950962 & KT950961 & - & - & - \\
\hline Farasanispora avicenniae & NFCCI-4220 & MG844277 & MG844281 & MG844285 & MG948548 & MG973031 \\
\hline Macrodiplodiopsis desmazieri & CBS123812 & KR873269 & - & KR873234 & - & - \\
\hline Massarina eburnea & H3953 & AB521735 & AF164367 & - & AB808517 & - \\
\hline Massarina ignaria & - & DQ810223 & DQ813511 & - & - & - \\
\hline Medicopsis romeroi & CBS 122784 & EU754208 & EU754109 & KF366447 & KF015679 & KF015707 \\
\hline Morosphaeria ramunculicola & BCC 18404 & GQ925853 & GU479760 & - & - & - \\
\hline Morosphaeria velatispora & BCC17058 & GQ925851 & GQ925840 & - & - & - \\
\hline Lentithecium fulviatile & CBS 123090 & FJ795450 & FJ795493 & - & - & FJ795467 \\
\hline Lentithecium arundinaceum & CBS123131 & GU456320 & GU456298 & - & GU456281 & - \\
\hline Pseudochaetosphaeronema & & & & & & - \\
\hline larense & CBS639.94 & KF015610 & KF015651 & KF015655. & KF015683 & \\
\hline Trematosphaeria hydrela & CBS88070 & KF314116 & - & - & KF314136 & - \\
\hline Trematosphaeria pertusa & CBS122368 & FJ201990 & - & NR132040 & - & - \\
\hline Ulospora bilgrami & AFTOLD1598 & DQ678076 & DQ678025 & - & DQ677921 & FJ795476 \\
\hline Verriculina enalia & BCC18402 & GU479803 & GU479771 & - & GU479864 & DQ677974 \\
\hline
\end{tabular}

Table 3 GenBank and culture collection accession numbers of species included in the phylogenetic study of Hysterium rhizophorae. Sequences generated in this study are in blue.

\begin{tabular}{|c|c|c|c|c|c|}
\hline \multirow{2}{*}{ Taxon } & \multirow{2}{*}{ Voucher/ Culture } & \multicolumn{4}{|c|}{ GenBank Accessions } \\
\hline & & LSU & SSU & ITS & RPB2 \\
\hline Hysterium angustatum & CBS 236.34 & FJ161180 & GU397359. & - & FJ161117 \\
\hline Hysterium angustatum & CBS123334 & FJ161207 & FJ161180 & - & GU566751 \\
\hline Hysterium angustatum & GKM5211 & GQ221906 & - & - & - \\
\hline Hysterium angustatum & SMH5216 & GQ221908 & - & - & - \\
\hline Hysterium angustatum & GKM243a & GQ221899 & - & - & - \\
\hline Hysterium angustatum & CMW:20409 & FJ161194 & FJ161153. & - & - \\
\hline Hysterium hyalinum & CBS:237.34 & FJ161181 & FJ161141 & - & - \\
\hline Hysterium barrianum & ANM1495 & GQ221885 & - & - & - \\
\hline Hysterium barrianum & ANM1442 & GQ221884 & - & - & - \\
\hline Hysterium pulicare & ANM85 & GQ221898 & - & - & - \\
\hline Hysterium pulicare & EB 0238 & FJ161201 & FJ161161 & - & FJ161127 \\
\hline Hysterium pulicare & CBS:119331 & - & - & EU552137 & - \\
\hline Hysterium pulicare & AFTOL-ID 1254 & DQ678055 & DQ678002 & - & FJ238433 \\
\hline Hysterium pulicare & ANM1455 & GQ221904 & - & - & - \\
\hline Hysterium vermiforme & GKM1234 & GQ221897 & - & - & - \\
\hline Hysterium rhizophorae & MFLU 16-1179 & KX611364 & KX611365 & KX611363 & - \\
\hline Hysterium rhizophorae & NFCCI-4250 & MG844276 & MG844280 & MG844284 & MG968956 \\
\hline Psiloglonium clavisporum & CBS: 123338 & FJ161197 & - & - & - \\
\hline Psiloglonium clavisporum & CBS: 123340 & FJ161205 & - & - & - \\
\hline
\end{tabular}

The phylogenetic analyses show that our new taxon Deniquelata vittalii clustered together with the strains of $D$. barringtoniae with a strong statistical support in a monophyletic clade (100\% 
ML, 100\%MP, 1.00 BYPP) in the family Didymosphaeriaceae. Deniquelata vittalii shares a sister relationship with $D$. barringtoniae with significant statistical support (88\% ML, 89\% MP, 1.00 BYPP, Fig. 1).

The second multigene phylogenetic analyses include 27 in-group taxa from different genera from Pleosporales, including our taxon, while Verruculina enalia served as the outgroup taxon (based on LSU, SSU, TEF-1 $\alpha$, ITS and RPB2 sequence data, Table 2). RAxML analysis yielded a best scoring tree (Fig. 2) with a final ML optimization likelihood value of -22392.941365 . The matrix had 1629 distinct alignment patterns, with $42.78 \%$ of undetermined characters or gaps. Estimated base frequencies were as follows; $\mathrm{A}=0.249321, \mathrm{C}=0.235804, \mathrm{G}=0.273367, \mathrm{~T}=$ 0.241508; substitution rates $\mathrm{AC}=1.425242, \mathrm{AG}=3.166282, \mathrm{AT}=1.605461, \mathrm{CG}=1.085865, \mathrm{CT}=$ 7.895025 , GT $=1.000000$; proportion of invariable sites $\mathrm{I}=0.436939$; gamma distribution shape parameter $\alpha=0.442521$. The maximum parsimony dataset consisted of 4613 characters with 3128 characters as constant, 1009 characters were counted as parsimony-informative and 476 characters as parsimony-uninformative. The parsimony analyses resulted in one equal parsimonious tree with a tree length of 3657 steps, $\mathrm{CI}=0.596, \mathrm{RI}=0.484, \mathrm{RC}=0.288, \mathrm{HI}=0.404$ values. Phylogenetic analyses indicate that both strains of Farasanispora avicenniae cluster together with high bootstrap support (100\% ML, 100\% MP, 1.00 BYPP, Fig. 2). Our phylogenies generated herein, under different criteria, yielded similar results as previously reported in connection to the uncertain familial placement of Farasanispora avicenniae (Li et al. 2016).

The phylogenetic analyses inferred from the third dataset include 19 taxa from Hysterium including our strain, while two strains of Psiloglonium clavisporum served as outgroup taxa (Table 3). RAxML analysis yielded a best scoring tree (Fig. 3) with a final ML optimization likelihood value of -9131.172652. The matrix had 297distinct alignment patterns, with $50.91 \%$ of undetermined characters or gaps. Estimated base frequencies were as follows; $\mathrm{A}=0.253481, \mathrm{C}=$ $0.222684, \mathrm{G}=0.285514, \mathrm{~T}=0.238321$; substitution rates $\mathrm{AC}=0.906683, \mathrm{AG}=1.276344, \mathrm{AT}=$ $0.828696, \mathrm{CG}=0.793370, \mathrm{CT}=2.357133, \mathrm{GT}=1.000000$; proportion of invariable sites $\mathrm{I}=$ 0.492153; gamma distribution shape parameter $\alpha=586.774160$. The maximum parsimonious dataset consists of 19 taxa with 3632 characters, of which 2500 were constant, 312 were parsimony-informative and 820 parsimony-uninformative. The parsimony analysis of the data matrix resulted in one hundred and ninety-eight equally parsimonious trees with a length of 1523 steps $(\mathrm{CI}=0.922, \mathrm{RI}=0.711, \mathrm{RC}=0.656, \mathrm{HI}=0.078)$. The molecular phylogeny indicates that both the strains of $H$. rhizophorae (MFLUCC161179 and NFCCI4250) nested together with significant bootstrap support of $77 \%$ in MP, $0.96 \%$ in BYPP and moderate support of $64 \%$ in ML (Fig. 3). Phylogenetic trees resulted from ML, MP, BYPP analyses were in congruent to the earlier study (Hyde et al. 2017).

\section{Taxonomy}

Deniquelata vittalii Devadatha, V.V Sarma, E.B.G Jones, sp. nov.

Fig. 4

MycoBank number: MB820842; Facesoffungi number: FoF04375

Etymology - In honour of Professor B.P.R. Vittal, formerly Professor in the University of

Madras, India for his contributions to Indian mycology

Holotype - AMH-9888

Saprobic on decaying woody stem of the halophyte Suaeda monoica. Sexual morph: Ascomata 95-360 $\mu \mathrm{m}$ high, $75-350 \mu \mathrm{m}$ in diameter $(\bar{x}=225 \times 212 \mu \mathrm{m}, \mathrm{n}=10)$, immersed to semiimmersed, erumpent, globose to sub-globose, dark brown to black, aggregated to solitary, obpyriform, coriaceous, fused with the host tissues, with a papillate to depressed ostiole. Peridium 10-40 $\mu \mathrm{m}(\bar{x}=23 \mu \mathrm{m}, \mathrm{n}=10)$ wide at the base, $10-55 \mu \mathrm{m}(\bar{x}=30 \mu \mathrm{m}, \mathrm{n}=10)$ at the sides, comprising 3-5 layers of thin-walled hyaline to pale brown cells inwardly and thick-walled pale brown to dark brown cells of textura angularis outwardly fused with the host tissue. Hamathecium composed of $1.5-3 \mu \mathrm{m}$ wide $(\bar{x}=2 \mu \mathrm{m}, \mathrm{n}=10)$, cellular, profusely branched, hyaline, septate 


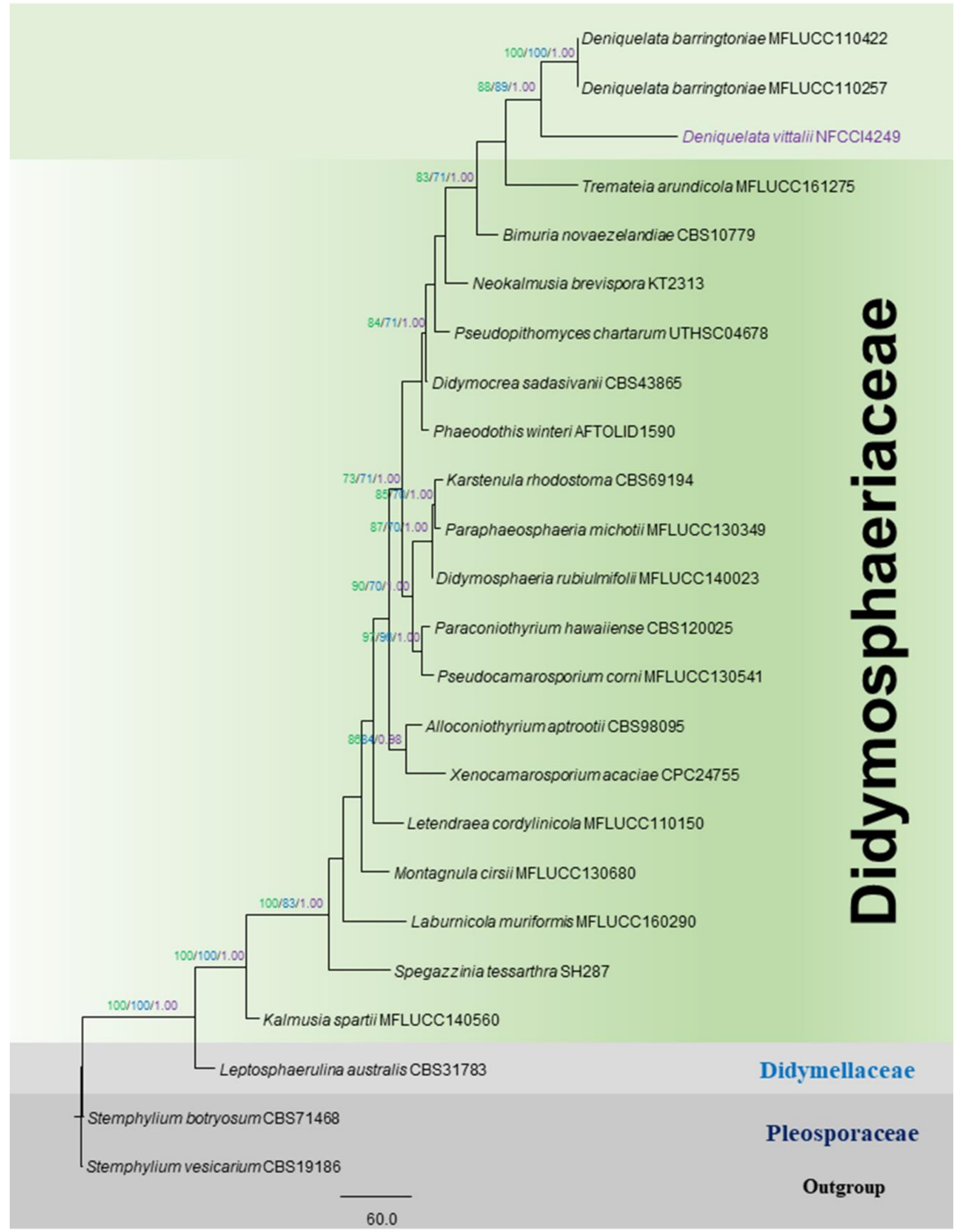

Figure 1 - Phylogram generated from maximum parsimony analysis based on a combined dataset of LSU, SSU and ITS. Bootstrap support values for maximum likelihood (ML, green), maximum parsimony (MP, blue) equal to or greater than $70 \%$ and the values of Bayesian posterior probabilities (BYPP, purple) equal to or greater than 0.95 are given above each branch, respectively. The new species is in purple colour. The tree is rooted with Stemphylium vesicarium and Stemphylium botryosum. 


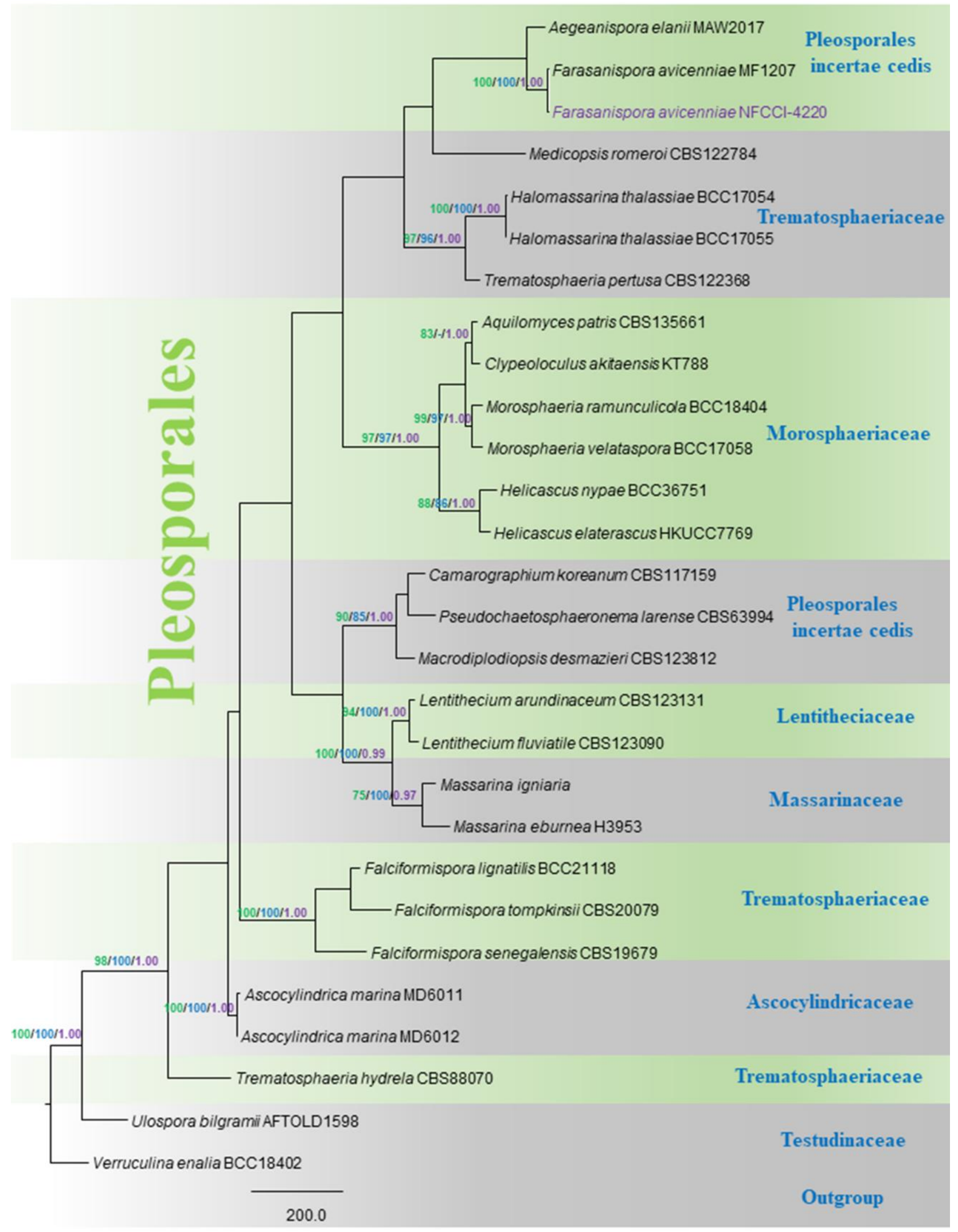

Figure 2 - Phylogram generated from maximum parsimony analysis based on combined LSU, SSU, TEF1, ITS and RPB2 sequence data of Farsanispora avicenniae NFCCI-4220 and other related taxa in Pleosporales. Verruculina enalia is the outgroup taxon. Bootstrap support values for maximum likelihood (ML, green), maximum parsimony (MP, blue) equal to or greater than $75 \%$ and the values of Bayesian posterior probabilities (BYPP, purple) equal to or greater than 0.95 are given above each branch, respectively. The new record is in purple colour. 


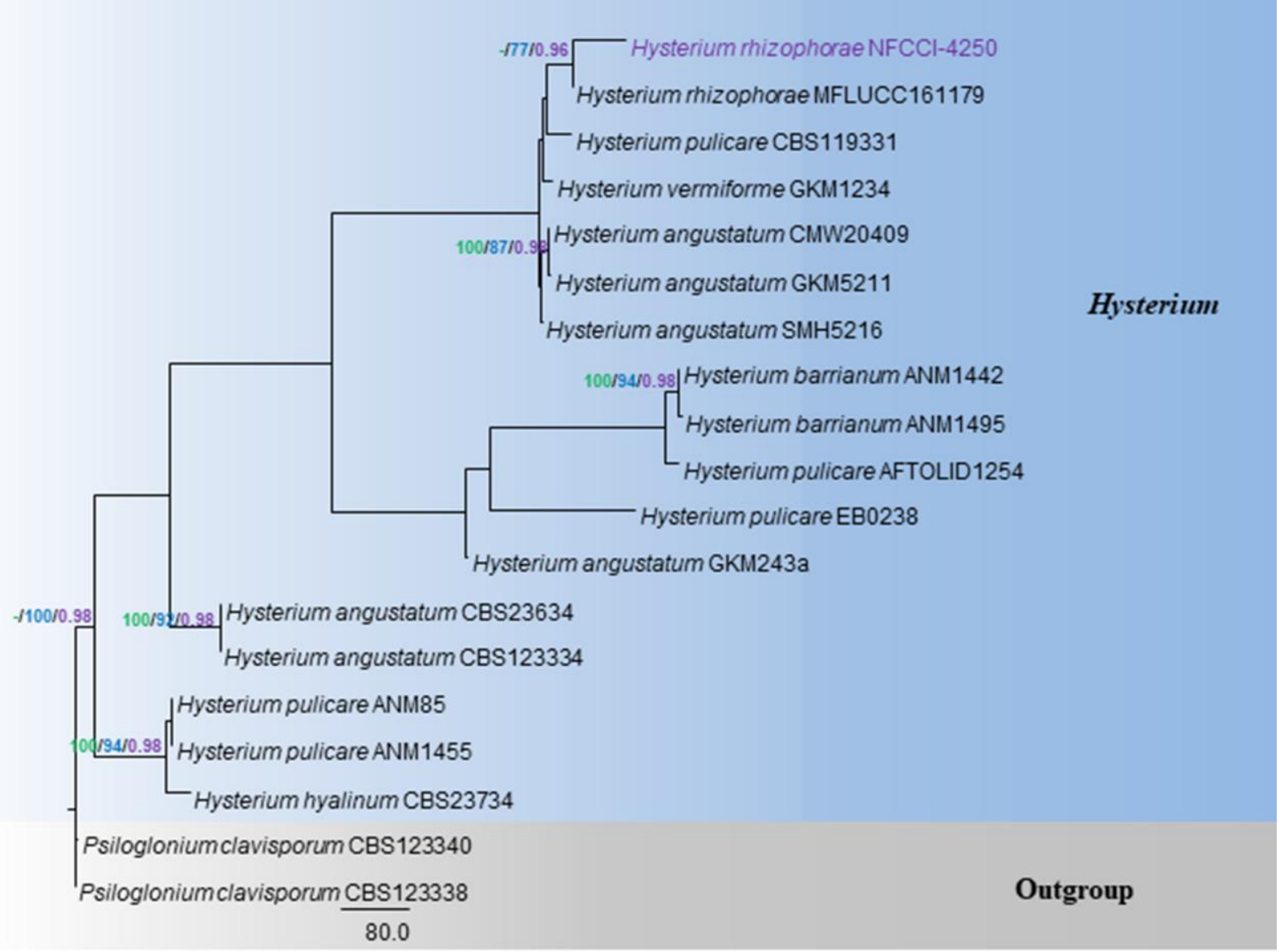

Figure 3 - Phylogram generated from maximum parsimony analysis based on combined LSU, SSU and RPB2 sequence data of selected taxa. Bootstrap support values for maximum likelihood (ML, green), maximum parsimony (MP, blue) equal to or greater than $75 \%$ and the values of Bayesian posterior probabilities (BYPP, purple) equal to or greater than 0.95 are given above each branch, respectively. The new record is in purple. The tree is rooted with Psiloglonium clavisporum.

pseudoparaphyses, anastomosing above the asci, enclosed in a gelatinous matrix. Asci $75-135 \times$ 10-19 $\mu \mathrm{m}(\bar{x}=98 \times 15 \mu \mathrm{m}, \mathrm{n}=30), 8$-spored, bitunicate, fissitunicate, cylindric-clavate to clavate, apically rounded with an ocular chamber, with a 7-15 $\mu \mathrm{m}$ long and broad furcate pedicel. Ascospores 18-26 × 7.5-13.5 $\mu \mathrm{m}(\bar{x}=22.5 \times 10.7 \mu \mathrm{m}, \mathrm{n}=50), 1-2$ seriate, muriform, hyaline when young, developing into golden yellow to dark brown at maturity, rarely guttulate, ellipsoidal to broadly oblong, planate, flat, verrucose, deeply constricted in the middle, slightly curved to straight, apically conical to elliptical, with 1-2 longitudinal septa in each cell, 3-6 transverse septate, lacking mucilaginous sheath. Asexual morph: Undetermined.

Culture characteristics - Ascospores germinating on 50\% sea water agar producing germ tubes at both ends of the ascospores within 24 hours. Colonies on MEA showed moderate growth attaining 20-24 mm in diameter within a week and reached 35-50 mm after 20 days of incubation at $25^{\circ} \mathrm{C}$, front pale ochraceous salmon, reverse capucine buff, with pale yellow diffusible pigments, margin filamentous, pulvinate, circular, cottony and fluffy.

Material examined - INDIA, Tamil Nadu, Tiruvarur, Muthupet mangroves $\left(10.4^{\circ} \mathrm{N} 79.5^{\circ} \mathrm{E}\right)$, on decaying woody stem of the halophyte Suaeda monoica (Amaranthaceae) 15 August 2015, B. Devadatha (AMH-9888, holotype), ex-type living culture NFCCI-4249.

Notes - Multigene analyses of LSU, SSU and ITS sequence data show that our new taxon belongs to the family Didymosphaeriaceae and is closely related to Deniquelata barringtoniae with a strongly-supported monophyletic clade (Fig. 1). Morphologically Deniquelata vittalii resembles the generic type Deniquelata barringtoniae in having sub-globose to globose ascomata, shorter 
papilla with a depressed ostiole; asci with short furcate pedicel and ascospores that are oblong, straight or slightly curved, muriform with 1-2 vertical septa, verruculose (Ariyawansa et al. 2013, 2014b). However, Deniquelata vittalii can be easily distinguished from D. barringtoniae in having larger ascomata, asci and ascospore dimensions (Fig. 4, Table 4). Deniquelata barringtoniae is distinct in having smaller, reddish-brown ascospores $(13-16 \times 5-7)$, with 3-transverse septa whereas D. vittalii has larger, brown ascospores (17.5-25 × 7.5-13.5) with 3-6 transverse septa (Fig. 4, o-s). Further, D. barringtoniae is pathogenic on living leaves of Barringtonia asiatica from terrestrial environments (Ariyawansa et al. 2013), while D. vittalii is saprobic on decaying woody stem of the halophyte Suaeda monoica from marine environments. Distinct nucleotide differences between Deniquelata vittalii and D. barringtoniae were noted across various gene regions analyzed [35 within ITS; 34 within LSU; 12 within SSU; 46] which comply with recommendations outlined by Jeewon \& Hyde (2016) to establish new species based on DNA sequence data. Hence the new species $D$. vittalii has been proposed to be accommodated in the genus Deniquelata.

Farasanispora avicenniae Abdel-Wahab, Bahkali \& E.B.G. Jones, Fungal Diversity. 78 : 63 (2016)

Facesoffungi number: FoF01635

Fig. 4

Saprobic on decaying woody stem of the halophyte Suaeda monoica. Sexual morph: Ascomata 170-330 $\mu \mathrm{m}$ high, 165-345 $\mu \mathrm{m}$ diam. $(\bar{x}=239 \times 240 \mu \mathrm{m}, \mathrm{n}=10)$, immersed to erumpent, sub globose, solitary to gregarious, coriaceous, dark brown to black, ostiolate. Peridium unequal in thickness, $18-40 \mu \mathrm{m}(\bar{x}=28 \mu \mathrm{m}, \mathrm{n}=10)$ wide at the sides comprising two different cell layers, outer layer of brown to hyaline polygonal cells fused with host tissue and thick inner layer composed of several hyaline flattened cells of textura angularis. Peridium less developed at the base $15-30 \mu \mathrm{m}(\bar{x}=22.5 \mu \mathrm{m}, \mathrm{n}=10)$ wide, hyaline to light brown cells fused with the host tissue. Hamathecium composed of $1.5-2.5 \mu \mathrm{m}(\bar{x}=2.1 \mu \mathrm{m}, \mathrm{n}=20)$ wide, numerous, septate, branched, filamentous pseudoparaphyses resembling hyphae embedded in a gelatinous matrix, anastomosing above the asci. Asci 70-135 $\times 20-32 \mu \mathrm{m}(\bar{x}=105 \times 26 \mu \mathrm{m}, \mathrm{n}=40), 8$-spored, bitunicate, fissitunicate, cylindrical to clavate, short pedicellate, apically rounded and thickened with an ocular chamber. Ascospores 30-37 $\times 7-15 \mu \mathrm{m}(\bar{x}=34 \times 11 \mu \mathrm{m}, \mathrm{n}=50)$, biseriately arranged, constricted at the septa, rugose, hyaline, fusiform,1-3 septate, the septum is sub-median, upper cell longer and wider, slightly curved, guttulate, lacking a mucilaginous sheath. Senescent ascospores are larger 35-42 $\times 10-15 \mu \mathrm{m}(\bar{x}=37 \times 12 \mu \mathrm{m}, \mathrm{n}=10)$, light brown, flattened, distinctly constricted at the middle septum, striate, verruculose, $2-3$ septate.

Asexual morph: After 25 days of fermentation in Czapek-Dox broth, oval to ellipsoidal chlamydospores were found, $8-25 \times 10-20 \mu \mathrm{m}(\bar{x}=15 \times 12.5 \mu \mathrm{m}, \mathrm{n}=10)$, hyaline to purple colour filamentous hyphae, pinkish diffusible pigments produced as extracellular metabolites (Fig. $6)$.

Culture characteristics - Ascospores germinating on seawater agar within 24 hours, germ tubes arising from terminal ends of the ascospores. Colonies on malt extract agar moderately growing, reaching 45-60 mm diameter after 25 days of incubation at room temperature, initially white to grey becoming dark grey to brown in older cultures, flexuous on surface, zonate, undulate, effuse, flattened, medium dense, reverse pink, producing diffusible pigments into media.

Material examined - INDIA, Tamil Nadu, Tiruvarur, Muthupet mangroves, decaying woody stem of the halophyte Suaeda monoica Lam. (Amaranthaceae), $\left(10.4^{\circ} \mathrm{N} 79.5^{\circ} \mathrm{E}\right), 29$ October 2016, B. Devadatha, (AMH-9911) living culture (NFCCI-4220).

Notes - Multigene phylogenetic analyses show that Farasanispora avicenniae (NFCCI-4220) belongs to the order Pleosporales sharing sister relation to Trematosphaeriaceae and Morosphaeriaceae and distantly related to Massarinaceae (Fig. 2). However, it did not group with any known family and formed a distinct monophyletic clade with the existing Farasanispora avicenniae (MF1207) with a high bootstrap support from (100\% ML, 100\%MP, 1.00 BYPP, Fig. 2) and shares a sister group relation to Aegeanispora elanii with a lower bootstrap support. Morphological characteristics of Farasanispora avicenniae occurring on the decaying woody stems 


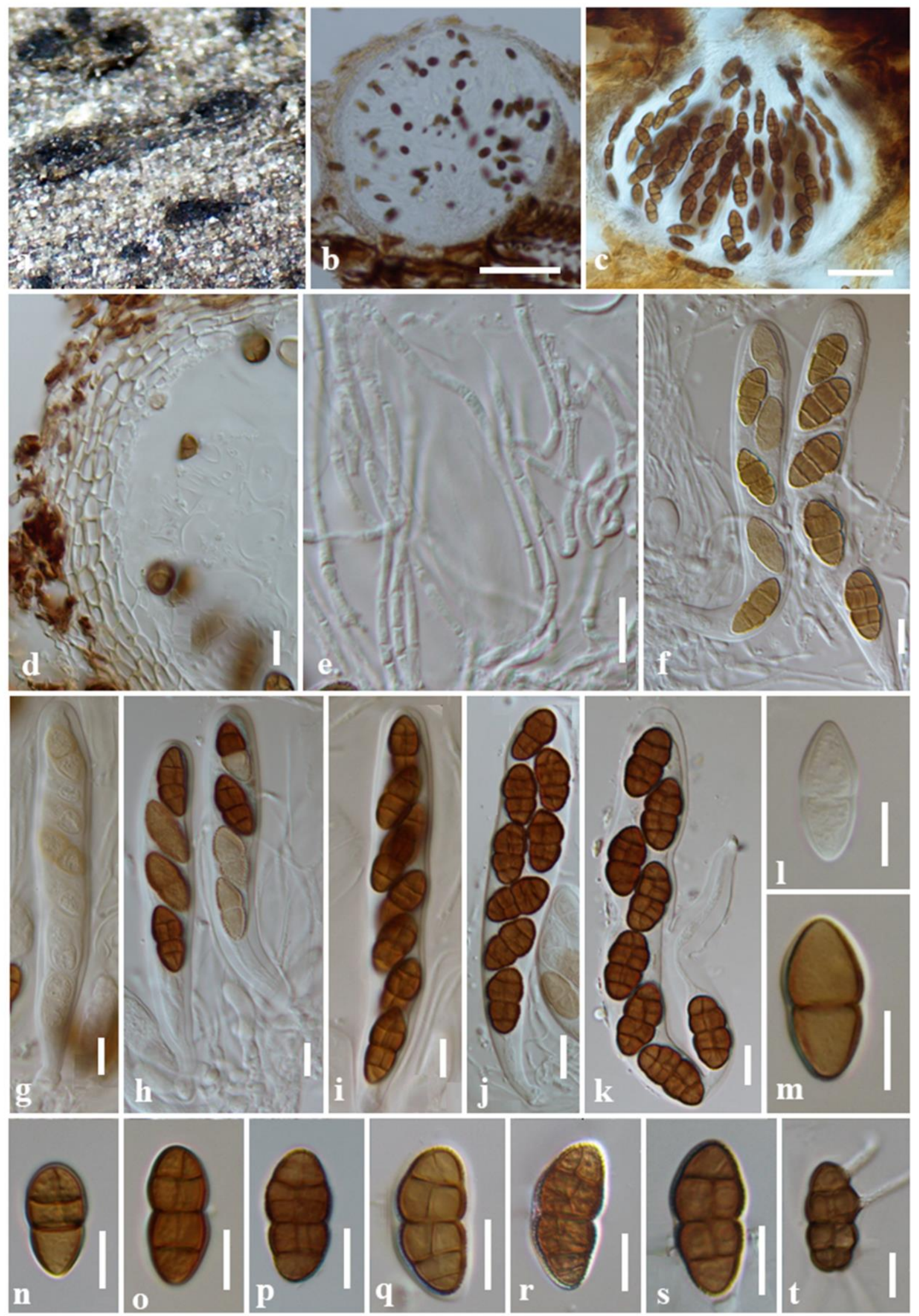

Figure 4 - Deniquelata vittalii (AMH-9888, holotype). a Ascomata semi-immersed in the decaying woody stem of the halophyte Suaeda monoica. b-c Longitudinal sections of ascomata d Section of peridium. e Cellular and hyaline pseudoparaphyses. f-k Immature and mature asci. 1-s Ascospores. $t$ Germinating ascospores. Scale bars: $b=100 \mu \mathrm{m}, c=50 \mu \mathrm{m}, \mathrm{d}-\mathrm{t}=10 \mu \mathrm{m}$. 
Table 4 Synopsis of morphological differences between Deniquelata vittalii and D. barringtoniae

\begin{tabular}{|c|c|c|}
\hline Species & Deniquelata barringtoniae & Deniquelata vittalii \\
\hline Host & Barringtonia asiatica & Suaeda monoica \\
\hline Life mode & Parasitic on leaves & Saprobic on decaying woody stems \\
\hline Habitat & Terrestrial & Marine \\
\hline Ascomata $(\mu \mathrm{m})$ & $150-180 \times 164-189$ & $100-350 \times 75-350$ \\
\hline $\begin{array}{l}\text { Peridium } \\
\text { thickness }(\mu \mathrm{m})\end{array}$ & $9-17$ & $10-40$ \\
\hline Asci $(\mu \mathrm{m})$ & $67-78 \times 10-15$ & $70-140 \times 10-20$ \\
\hline Ascospores $(\mu \mathrm{m})$ & $\begin{array}{l}13-16 \times 5-7 \text {, oblong, reddish brown to dark } \\
\text { yellowish brown, } 3 \text {-transverse septa and } 1-2 \\
\text { longitudinal septa }\end{array}$ & $\begin{array}{l}17.5-25 \times 7.5-13.5 \text {, golden yellow to dark brown, } \\
\text { deeply constricted in the middle, } 3-5 \text { transverse } \\
\text { septate, } 1-2 \text { longitudinal septa in each cell }\end{array}$ \\
\hline References & Ariyawansa et al. (2013) & This study \\
\hline
\end{tabular}

of halophyte Suaeda monoica, reported in the present study, are similar to Farasanispora avicenniae reported from Avicennia marina (Li et al. 2016). However, its occurrence on Suaeda monoica, in India, constitute new host and geographic records. Farasanispora avicenniae shares similar morphological characters with Halomassarina thalassiae (Kolhm. \& Volkm -Kohlm.) Suetrong et al. (Suetrong et al. 2009). However, it differs from Halomassarina thalassiae (Suetrong et al. 2009, Li et al. 2016) in having smaller ascomata, without a clypeus or papillae and in the absence of periphyses in the ostiolar canal, lacking senescent ascospores and a prominent gelatinous sheath (Fig. 5) (Kohlmeyer \& Kohlmeyer 1987). Prior to the present study, only LSU and SSU gene sequence data of $F$. avicenniae were available (Li et al. 2016). This study provided ITS, TEF- $1 \alpha$ and RPB2 in addition to LSU and SSU (Table 2).

Hysterium rhizophorae Dayarathne \& K. D. Hyde, in Fungal Diversity 87:42 (2017)

Fig. 7

Facesoffungi number: FoF02911

Saprobic on decaying wood of Aegiceras corniculatum. Sexual morph Ascomata hysterothecial, $650-2100 \mu \mathrm{m}$ long $(\bar{x}=1060 \mu \mathrm{m}, \mathrm{n}=5), 100-400 \mu \mathrm{m}$ high, $170-200 \mu \mathrm{m}$ wide $(\bar{x}$ $=243 \times 199 \mu \mathrm{m}, \mathrm{n}=5$ ), erumpent to superficial with base immersed, solitary to gregarious, straight to flexuous, ellipsoid or elongate, with pointed ends, opening by a depressed longitudinal slit, in vertical section sub-globose to globose, carbonaceous, black. Peridium $25-75(\bar{x}=50 \mu \mathrm{m}, \mathrm{n}=5)$ $\mu \mathrm{m}$ wide, carbonaceous, comprising an outer layer of dark brown cells of textura globosa and an inner layer of hyaline to pale brown cells of textura globosa. Pseudoparaphyses $1-2 \mu \mathrm{m}(\mathrm{n}=30)$ wide, cellular, septate, flexuous, branched. Asci 40-65 × 6-12 $\mu \mathrm{m}(\bar{x}=48 \times 10 \mu \mathrm{m}, \mathrm{n}=20), 8$ spored, bitunicate, cylindric to claviform, short pedicellate. Ascospores $10-17 \times 3-5 \mu \mathrm{m}(\bar{x}=14 \times$ $4 \mu \mathrm{m}, \mathrm{n}=30$ ), overlapping biseriate, light brown, ellipsoidal, straight to slightly curved, with 3transverse septa, often slightly constricted at the median septum, with or without guttules. Asexual morph: Undetermined.

Culture characteristics - Ascospores germinated on sea water agar within 24 hours, germ tubes arisen from terminal ends of the ascospore. Colonies on malt extract agar reaching 30-75 mm diameter after 25 days of incubation at room temperature, initially hyaline becoming ash grey in older cultures and reverse light brown, irregular, undulate, floccose.

Material examined - INDIA, Tamil Nadu, Tiruvarur, Muthupet mangroves, on intertidal

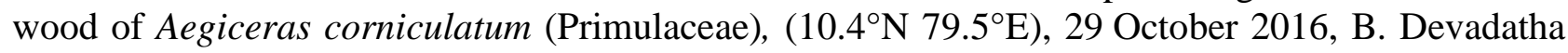
(AMH-9947), living culture (NFCCI-4250).

Notes - Combined phylogenetic analyses of LSU, SSU, ITS and RPB2 sequence data placed our taxon (Hysterium rhizophorae NFCCI4250) in the family Hysteriaceae and clustered together with Hysterium rhizophorae (MFLUCC161179) in a monophyletic clade with a significant bootstrap support from MP 77\%, BYPP $0.96 \%$ and moderate support in ML 64\% (Fig. 3). This Hysterium species was found on the decaying wood of Aegiceras corniculatum having overlapping 

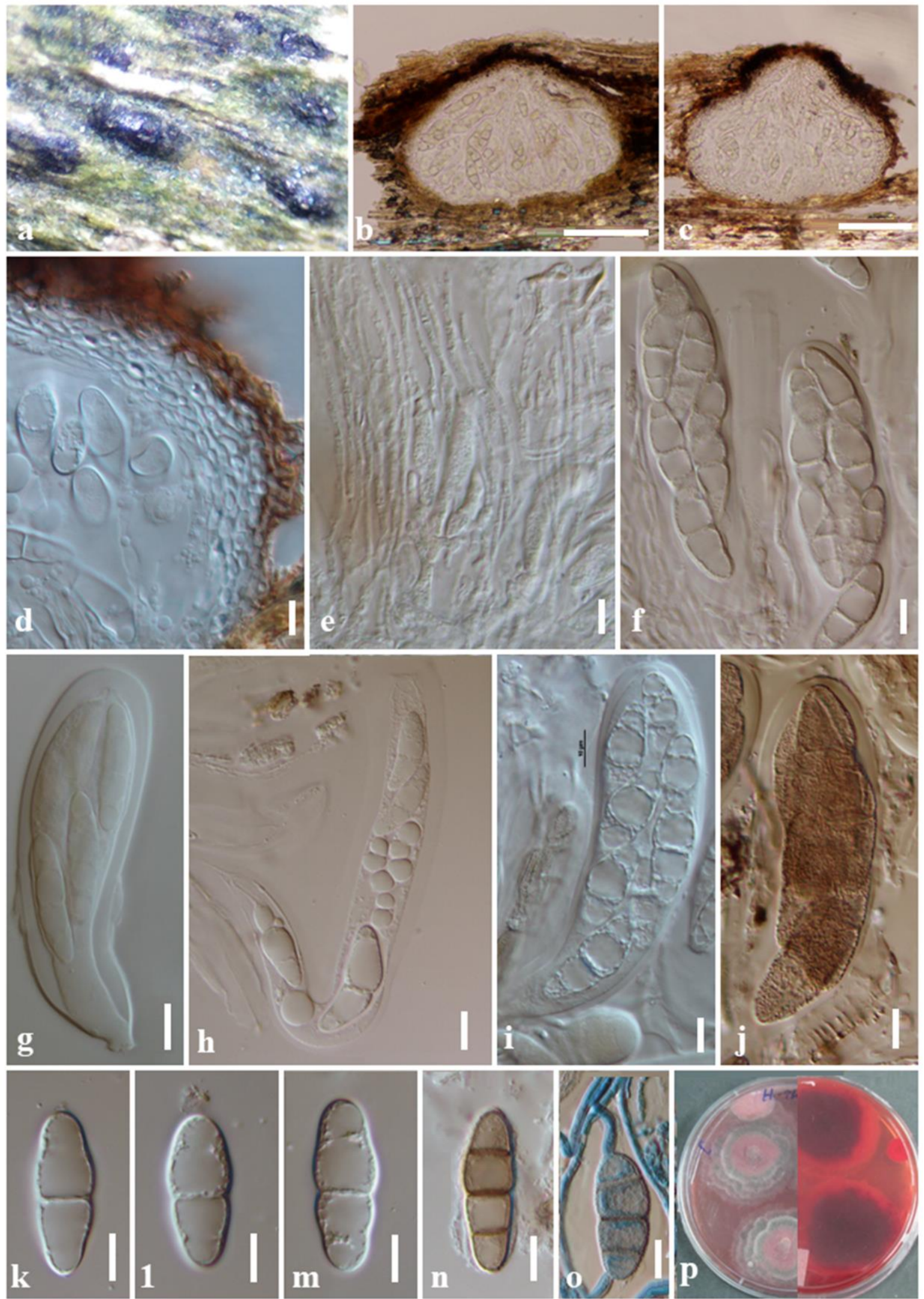

Figure 5 - Farasanispora avicenniae (AMH-9911). a Ascomata erumpent on the decaying wood of Suaeda monoica. b-c Longitudinal sections of ascomata d Section of peridium e filamentous pseudoparaphyses. f-j Immature and mature asci. k-m Hyaline ascospores. n Mature senescent ascospore. o Germ tubes developed from terminal ends of ascospore $p$ Culture. Scale bars: $\mathrm{b}-\mathrm{c}=100 \mu \mathrm{m}, \mathrm{d}-\mathrm{O}=10 \mu \mathrm{m}$. 

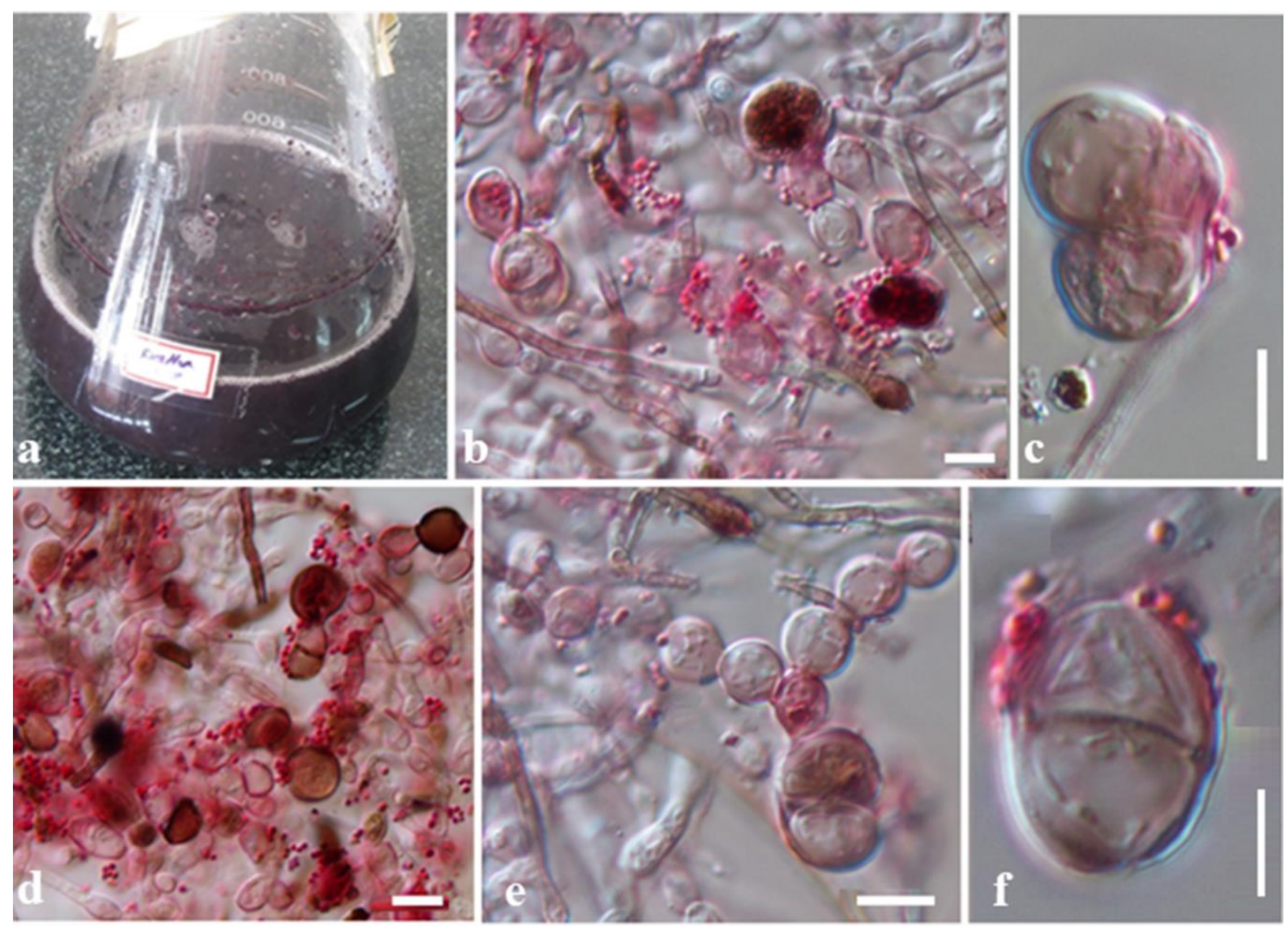

Figure 6 - Farasanispora avicenniae (NFCCI-4220). a Fermented culture in Czapek-Dox broth. $\mathrm{b}$, d hyphae showing development of chlamydospores and pink pigments. c, e-f chlamydospores. Scale bars: $\mathrm{b}-\mathrm{c}=100 \mu \mathrm{m}, \mathrm{d}-\mathrm{O}=10 \mu \mathrm{m}$.

morphological characters with Hysterium rhizophorae reported from Rhizophora apiculata (Hyde et al. 2017). The occurrence of $H$. rhizophorae on a new host i.e. A. corniculatum increases its host range and also this is the first report of this fungus from India thus expanding its geographical range. ITS pairwise alignment resulted in a very low (3) base pair difference with ITS sequence data of the two strains of $H$. rhizophorae (Jeewon \& Hyde 2016). Previously only ITS, LSU, SSU and TEF-1 $\alpha$ gene sequences were carried out (Hyde et al. 2017). The present study provides additional information on RPB2 sequence in the GenBank (RPB2: MG968956) in addition to the ITS, LSU and SSU gene sequence data for the new record.

\section{Discussion}

The monotypic genus Deniquelata typified by $D$. barringtoniae was established by Ariyawansa et al. (2013) who reported this fungus as a pathogen on living leaves of Barringtonia asiatica with brown spots and fruiting bodies scattered in the necrotic tissues (Ariyawansa et al. 2013, 2014b). The pathogenic nature of Deniquelata barringtoniae was proved by in vitro pathogenicity testing of healthy leaves of Barringtonia asiatica (Ariyawansa et al. 2013).

Multi-gene analyses showed that Deniquelata vittalii nested together with $D$. barringtoniae with significant bootstrap support (88\% ML, 89\% MP, 1.00 BYPP, Fig. 1) and separated from Bimuria novae-zelandiae and Tremateia arundicola sister groups. Deniquelata and Bimuria share similarities in having scattered, semi-immersed, sub-globose ascomata with muriform ascospores and are saprobic (D. vittalii and B. novae-zelandiae). Deniquelata species distinct from Bimuria typified by $B$. novae-zelandiae, in having shorter papilla with a depressed ostiole; 8 -spored asci with short furcate pedicel and ascospores that are oblong, straight or slightly curved, muriform with 

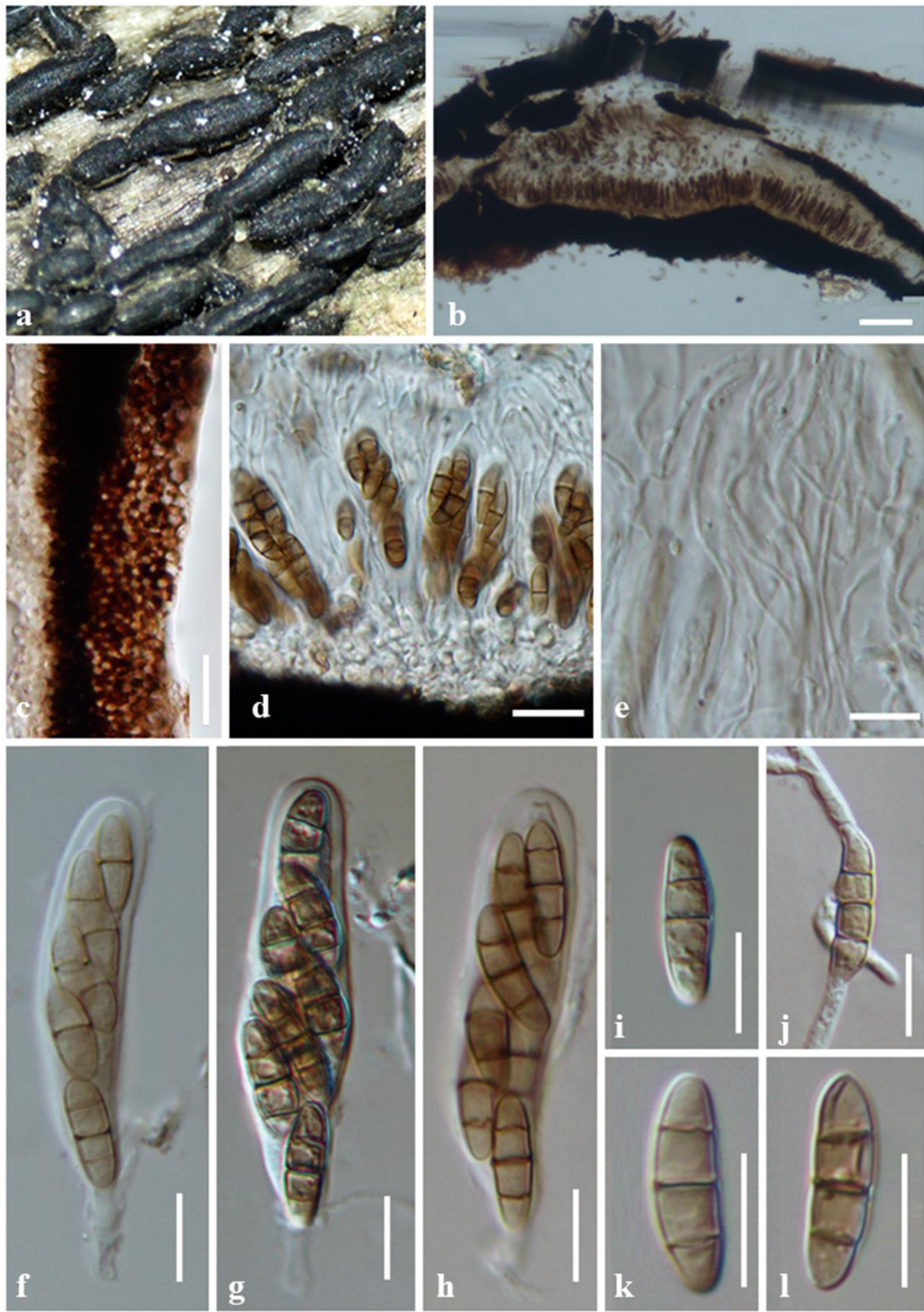

Figure 7 - Hysterium rhizophorae (AMH-9947) a Appearance of hysterothecia on host. b Vertical section through hysterothecium. c, d Peridium. e Pseudoparaphyses. f-h Asci. i, k-1 Ascospores. j Germinating ascospores. Scale bars: $\mathrm{b}=100 \mu \mathrm{m}, \mathrm{c}-\mathrm{k}=10 \mu \mathrm{m}$. 
3-6 transverse septa, 1-2 vertical septa, verruculose. Bimuria novae-zelandiae has 2-3-spored asci with short and small knob-like pedicel and comparatively larger ascospores with 5-7 transverse septa, without vertical septa, verrucose and by occurring in terrestrial habitat (Hawksworth 1979, Ariyawansa et al. 2013). The species in Tremateia can be clearly distinguished from Deniquelata species in having clavate to broadly clavate, short pedicellate, long asci and ellipsoid ascospores with 3-6 transverse septa and 1 vertical septum in each row (Kohlmeyer et al 1995, Hyde et al 2016).

This study provides sequence data of protein coding genes RPB2 and TEF1 $\alpha$ (MF168942, MF182398) in GenBank for Deniquelata vittalii whereas we lack these sequences data of $D$. barringtoniae for a comparison. This is the first report of a Deniquelata species from marine habitats (Jones et al. 2015). Recently (Devadatha \& Sarma 2018) reported a new species, Pontoporeia mangrovei from decaying woody stem of the halophyte Suaeda monoica. By adding the present new taxon, Suaeda monoica could be considered as a host that supports several novel marine fungi.

Farasanispora avicenniae and Hysterium rhizophorae were recorded for the first time from India and hence constitute new geographic records. Also, their occurrence on new hosts extend their host range. The present study provides new sequences data for these two-known species.

\section{Acknowledgements}

We would like to thank the Ministry of Earth sciences, Govt. of India for funding a project to carry out studies on Marine fungi from Muthupet mangroves (Sanction order: MOES/36/OO1S/Extra/40/2014/PC-IV dt.14.1.2015). We thank the District Forest Office, Tiruvarur, Tamil Nadu and PCCF (Head of Forest Force), Chennai, Tamil Nadu Forest Department, India for providing permission to collect samples from Muthupet mangroves. Department of Biotechnology, Pondicherry University is thanked for providing the facilities. B. Devadatha would like to thank the Ministry of Earth Sciences, Govt. of India for providing a fellowship and also grateful to Dhanushka Nadeeshan of Mae Fah Luang University, Thailand for his valuable suggestions and help. H.A. Ariyawansa thanks the Ministry of Science and Technology, Taiwan (MOST project ID: 106-2621-B-002-005-MY2) for a partial funding of this work. We thank the anonymous reviewers for their suggestions to improve the manuscript.

\section{References}

Aptroot A. 1995 - A monograph of Didymosphaeria. Studies in Mycology 37, 1-160.

Ariyawansa HA, Maharachchikumbura SS, Karunarathne SC, Chukeatirote E et al. 2013 Deniquelata barringtoniae gen. et sp. nov., associated with leaf spots of Barringtonia asiatica. Phytotaxa. 105, 11-20.

Ariyawansa HA, Camporesi E, Thambugala KM, Mapook A et al. 2014a - Confusion surrounding Didymosphaeria phylogenetic and morphological evidence suggest Didymosphaeriaceae is not a distinct family. Phytotaxa 176, 102-119.

Ariyawansa HA, Tanaka K, Thambugala KM, Phookamsak R et al. 2014b - A molecular phylogenetic reappraisal of the Didymosphaeriaceae (= Montagnulaceae). Fungal Diversity 68, 69-104.

Bisby GR. 1923 - The literature on the classification of the Hysteriales. Transactions of the British Mycological Society 8, 176-189.

Chomnunti P, Hongsanan S, Aguirre-Hudson B, Tian Q et al. 2014 - The sooty moulds. Fungal Diversity 66, 1-36.

Devadatha B, Sarma VV. 2018 - Pontoporeia mangrovei sp.nov., a new marine fungus from an Indian mangrove along with a new geographical and host record of Falciformispora lignalitis. Current Research in Environmental \& Applied Mycology 8, 238-246. 
Devadatha B, Sarma VV, Wanasinghe DN, Hyde KD, Jones EBG 2017 - Introducing the new Indian mangrove species, Vaginatispora microarmatispora (Lophiostomataceae) based on morphology and multigene phylogenetic analysis. Phytotaxa 329, 139-149.

Devadatha B, Sarma VV, Jeewon R, Wanasinghe DN et al. 2018 - Thyridareilla a novel marine fungal genus from India: morphological characterization and phylogeny inferred from multigene DNA sequence analyses. Mycological Progress 1-14. https://doi.org/10.1007/s11557-018-1387-4

Hall TA. 1999 - BioEdit: a user- friendly biological sequence alignment editor and analysis program for Windows 95/98/NT. Nucleic Acids Symposium Series 41, 95-98.

Hawksworth DL, Yen CC, Edmund J. 1979 - Bimuria novae-zelandiae gen. et sp. nov., a remarkable ascomycete isolated from a New Zealand barley field. New Zealand journal of botany 17, 267-273.

Huelsenbeck JP, Ronquist F. 2001 - MRBAYES: Bayesian inference of phylogenetic trees. Bioinformatics 17, 754-755.

Hyde KD, Jones EBG, Liu JK, Ariyawansa H et al. 2013 - Families of Dothideomycetes. Fungal Diversity 63, 1-313.

Hyde KD, Hongsanan S, Jeewon R, Bhat DJ et al. 2016 - Fungal diversity notes 367-490: taxonomic and phylogenetic contributions to fungal taxa. Fungal Diversity 80, 1-270.

Hyde KD, Norphanphoun C, Abreu VP, Bazzicalupo A et al. 2017 - Fungal diversity notes 603708: taxonomic and phylogenetic notes on genera and species. Fungal Diversity 87, 1-235.

Kohlmeyer J, Volkman-Kohlmeyer B. 1987 - Marine fungi of Aldabra, the Galapagos, and other tropical islands. Canadian Journal of Botany 65, 571-582

Kohlmeyer J, Volkmann-Kohlmeyer B, Eriksson OE. 1995 - Fungi on Juncus roemerianus 2. New dictyosporous ascomycetes. Botanica Marina. 38, 165-174.

Jayasiri CS, Hyde KD, Ariyawansa HA, Bhat DJ et al. 2015 - The Faces of Fungi database: fungal names linked with morphology, phylogeny and human impacts. Fungal Diversity 74, 3-18.

Jeewon R, Hyde KD. 2016 - Establishing species boundaries and new taxa among fungi: recommendations to resolve taxonomic ambiguities. Mycosphere 7, 1669-1677.

Jones EBG, Suetrong S, Sakayaroj J, Bahkali AH et al. - 2015 - Classification of marine Ascomycota, Basidiomycota, Blastocladiomycota and Chytridiomycota. Fungal Diversity 73, $1-72$.

Katoh K, Standley K. 2013 - MAFFT Multiple Sequence Alignment Software Version 7: Improvements in Performance and Usability. Molecular Biology \& Evolution 30, 772-780.

Kishino H, Hasegawa M. 1989 - Evaluation of the maximum likelihood estimate of the evolutionary tree topologies from DNA - sequence data, and the branching order in Hominoidea. Journal of Molecular Evolution 29, 170-179.

Li GJ, Hyde KD, Zhao RN, Hongsanan S et al. 2016 - Fungal diversity notes 253-366: taxonomic and phylogenetic contributions to fungal taxa. Fungal Diversity 78, 1-237.

Liu YJ, Whelen S, Hall BD. 1999 - Phylogenetic relationships among ascomycetes: evidence from an RNA polymerase II subunit. Molecular Biology and Evolution 16, 1799-1808.

Miller MA, Pfeiffer W, Schwartz T. 2010 - Creating the CIPRES science gateway for inference of large phylogenetic trees. In Proceedings of the Gateway Computing Environments Workshop (GCE). San Diego Supercomput. Center, New Orleans, 1-8.

Munk A. 1953 - The system of the pyrenomycetes. A contribution to a natural classification of the group Sphaeriales sensu Lindau. Dansk Botanisk Arkiv 15, 1-163.

MycoBank. 2017 - available from: http://www.MycoBank .org/- (accessed: October 2017).

Nylander JAA. 2004 - MrModeltest v2 Program distributed by the author. Evolutionary Biology

Centre, Uppsala University, Uppsala.

Rambaut A. 2012 - FigTree v. 1.4.0. http://tree.bio.ed.ac.uk/software/figtree/

Rambaut A, Drummond AJ. 2007 - Tracer ver. 1.4. Available at http://tree. bio. ed. ac. uk/software/tracer. 
Rannala B, Yang Z. 1996 - Probability distribution of molecular evolutionary trees: a new method of phylogenetic inference. Journal of Molecular Evolution 43, 304-311.

Rehner SA, Buckley E. 2005 - A Beauveria phylogeny inferred from nuclear ITS and EF1- $\alpha$ sequences: evidence for cryptic diversification and links to Cordyceps teleomorphs. Mycologia 97, 84-98

Schoch CL, Crous PW, Groenewald JZ, Boehm EWA et al. 2009 - A class- wide phylogenetic assessment of Dothideomycetes. Studies in Mycology 64, 1-15.

Stamatakis A, Hoover P, Rougemont J. 2008 - A rapid bootstrap algorithm for the RAxML webservers. Systematic Biology 57, 758-771.

Stamatakis A. 2014 - RAxML version 8: a tool for phylogenetic analysis and post-analysis of large phylogenies. Bioinformatics. 30, 1312-1313.

Suetrong S, Schoch CL, Spatafora JW, Kohlmeyer J et al. 2009 - Molecular systematics of the marine Dothideomycetes. Studies in Mycology 64, 155-173.

Swofford DL. 2002 - PAUP*: Phylogenetic analysis using parsimony, Version 4.0b10. Sinauer Associates, Suderland.

Vilgalys R, Hester M. 1990 - Rapid genetic identification and mapping of enzymatically amplified ribosomal DNA from several Cryptococcus species. Journal of Bacteriology 172, 42384246.

White T, Bruns T, Lee S, Taylor J. 1990 - Amplification and direct sequencing of fungal ribosomal RNA genes for phylogenetics. PCR Protocols: A Guide to Methods and Applications 18, $315-322$.

Wijayawardene NN, Hyde KD, Rajesh Kumar KC et al. 2017 - Notes for genera: Ascomycota. Fungal Diversity 86, 1-594.

Zhaxybayeva O, Gogarten JP. 2002 - Bootstrap, Bayesian probability and maximum likelihood mapping: exploring new tools for comparative genome analyses. BMC genomics 3, 4 . 